\title{
THE DETECTION OF THE TIME OF CONVERSION FROM VEGETATIVE TO REPRODUCTIVE GROWTH IN Swainsona formosa (FABACEAE)
}

\section{[PENENTUAN WAKTU PERUBAHAN DARI PERTUMBUHAN VEGETATIF KE REPRODUKTIF PADA Swainsona formosa (FABACEAE)]}

\author{
Zulkarnain \\ Agricultural Faculty University of Jambi, Indonesia \\ Email: dr.zulkarnain@yahoo.com
}

\begin{abstract}
The induction of chromosome doubling using antimitotic chemical will only be effective when the substance is applied at vegetative growth phase, as it works only during mitotic division within cells of actively growing tissues. Therefore, this investigation was carried out to determine the precise conversion time from vegetative into reproductive growth stage, that in turn can be used as a reliable reference for the application of antimitotic chemicals in doubling the chromosome number in Swainsona formosa. The conversion from vegetative to reproductive growth in Swainsona formosa was successfully determined with particular emphasis on the effect of different photoperiods. Although photoperiod affected the time required for first flower initiation, the number of nodes before the plant entering the reproductive stage was not affected by photoperiod and presumed to be set genetically. It was found that under artificial photoperiods of 16,12 and 8 hours the $12^{\text {th }}$ and $11^{\text {th }}$ nodes were the critical nodes for the main and side stems, respectively. Meanwhile the $10^{\text {th }}$ and $8^{\text {th }}$ nodes were found to be critical for main and side stems of plants grown under natural photoperiods ranging from 12 to 16 hours during their life cycle. Histological examination indicated that when the plants were grown under $12-16$ hours photoperiods the first floral bud formation was initiated within $56-60$ days after germination, thus this period was considered as the critical time for the conversion from vegetative to reproductive growth in $S$. formosa.
\end{abstract}

Keywords: Sturt's desert pea, legume, ornamental plant, plant breeding.

\begin{abstract}
ABSTRAK
Induksi penggandaan kromosom menggunakan senyawa kimia antimitotik akan efektif jika dilakukan pada fase pertumbuhan vegetatif, karena senyawa tersebut hanya bekerja selama pembelahan mitosis sel-sel pada jaringan yang tengah aktif tumbuh. Oleh karena itu, penelitian ini dilakukan untuk menentukan waktu perubahan yang tepat dari fase pertumbuhan vegetatif ke reproduktif, yang pada gilirannya dapat digunakan sebagai referensi untuk aplikasi bahan kimia antimitotik dalam menggandakan jumlah kromosom pada Swainsona formosa. Waktu perubahan dari fase pertumbuhan vegetatif ke pertumbuhan reproduktif pada $S$. formosa berhasil ditentukan dengan penekanan khusus pada pengaruh fotoperiodesitas. Hasil penelitian menunjukkan, bahwa meskipun fotoperiodesitas mempengaruhi lama waktu untuk inisiasi bunga pertama, namun jumlah nodus sebelum tanaman memasuki tahap reproduktif tidak dipengaruhi oleh fotoperiodesitas, dan diduga dikendalikan secara genetik. Di bawah fotoperiodesitas buatan selama 16, 12 dan 8 jam, nodus ke-12 dan 11 adalah nodus kritis untuk masing-masing batang utama dan tunas samping. Sementara itu nodus ke-10 dan 8, menjadi penting bagi batang utama dan tunas samping pada tanaman yang ditanam di bawah fotoperiodesitas alami mulai dari 12 hingga 16 jam per hari selama siklus hidupnya. Pemeriksaan histologi menunjukkan bahwa ketika tanaman ditanam di bawah kondisi fotoperiodesitas 12 - 16 jam, pembentukan kuncup bunga pertama dimulai dalam waktu 56 - 60 hari setelah perkecambahan, sehingga periode ini dianggap sebagai waktu kritis untuk konversi dari pertumbuhan vegetatif ke reproduktif pada S. formosa.
\end{abstract}

Kata kunci: Sturt's desert pea, legum, tanaman hias, pemuliaan tanaman. 


\section{INTRODUCTION}

One of the key factors influencing success in the induction of polyploidysation using antimitotic chemicals is the age of the plant materials in relation to their life cycle. Most chromosome doubling protocols aimed at producing tetraploid plants were reported to be effective when colchicine or oryzalin was applied during the vegetative stage of the life cycle of the plant (Lucket, 1989; Bruner, 1998; McCuistion and Wehner, 2002; Zulkarnain, 2004). This is because these chemicals will work to inhibit spindle formation and prevent the separation of chromosomes during mitosis only in actively growing tissues.

An antimitotic chemical can be applied by soaking the scales, tubers or bulbs of plants prior to culture, or by coating young seedlings in the glasshouse for a certain period. The treatment of scales was found to be effective in doubling the chromosome number in Cyclamen persicum (Takamura and Miyajima, 1996). With Musa spp., polyploidysation was successfully induced by soaking the sucker in the antimitotic solution prior to in vitro culture (Azhar and Rusli, 2000). Meanwhile, treating seeds by soaking them in antimitotic solution has been found to be effective in obtaining tetraploids in Vicia faba (Joshi and Verma, 2004) and V. villosa (Tulay and Unal, 2010). However, Bruner (1998), Lucket (1989), McCuistion and Wehner (2002) and Zulkarnain (2004) claimed that of all the methods of application, shoot apex treatment at the seedling stage was found to be most effective in Passiflora incarnata, Gossypium hirsutum, Citrulus vulgaris and Swainsona formosa.

It is clear that polyploidy induction should be done during the vegetative stage of plant growth to ensure the production of polyploid cells during subsequent growth. Then, when entering the reproductive stage, the plant will develop male and female gametes that are expected to have $2 x$ chromosomes. It is important to note that once conversion to floral apices has occurred, application of any antimitotic agents will no longer be effective.

We report here the first work, so far, on the detection of conversion time from vegetative to reproductive growth in $S$. formosa. We also investigate the seasonal influence that affects this conversion on plants grown under natural photoperiod in the glasshouse or under artificial photoperiod in growth chambers.

\section{MATERIALS AND METHODS}

The trial consisted of two separated experiments. The first experiment was conducted in the glasshouse with photoperiod ranging from 12 to 16 hours per day and 
light intensity from 650 to $1200 \mu \mathrm{mol} \mathrm{m} \mathrm{m}^{-2}$. The day/night temperatures were set at $30 / 20^{\circ} \mathrm{C}$. Plant materials were sampled at $14,28,35,42,49,56,60,64,65$ and 66 days after germination. Four plants were sampled for each treatment.

The specimens (shoot tips) were collected according to the designated time. Immediately after being isolated from the plants, the shoots were fixed in FPA solution until required. The next step followed the procedure established by Prakash (2000). The procedure involved dehydration through a series of tertiary butyl alcohol (TBA) solutions for 2 hours in each grade ('50', '70', ' 85 ', ' 95 ', ' 100 '). After dehydration was completed, the specimens were infiltrated with paraplast, before being embedded in a wax block. The wax block with specimen was then sectioned to a thickness of $12 \mu \mathrm{m}$, and mounted on a microscope slide with the aid of Haupt's solution (an adhesive), and left dried in an oven $\left(40^{\circ} \mathrm{C}\right)$ overnight. The specimens were cleared in histolene-alcohol solution, and stained with $1 \%$ aqueous safranine for 24 hours followed by $0.5 \%$ fast-green for 10 seconds. Having been stained with safranine and fast-green, the specimens were mounted permanently using a few drops of Euparal (a synthetic resin), and covered with a cover slip (No. 1 thickness), and left dried in an oven $\left(40^{\circ} \mathrm{C}\right)$ for 48 hours.

At the same time, another experiment was also conducted in the same glasshouse. This experiment consisted of 100 plants that were grown and examined for the number of nodes before the first flower. Data were taken from the central stem and two axillary branches growing from the base.

In order to obtain a complete picture of seasonal influence (photoperiod) on the conversion of vegetative to reproductive growth, another experiment was set up in the growth cabinets. This experiment was performed in three growth cabinets each of different photoperiod i.e. 8-, 12- and 16-hour per day, respectively. Light intensity was the same for all cabinets ranging from 150 to $1000 \mu \mathrm{mol} \mathrm{m} \mathrm{m}^{-2}$ during the light hours to mimic that of natural glasshouse conditions. The day/night temperatures were set to $30 / 20^{\circ} \mathrm{C}$ for all cabinets. Twenty plants were used as replicates for each photoperiod tested. Plant growth and development were observed weekly and data on the number of nodes before the first flower were taken from the central stem and two axillary branches. 


\section{RESULTS}

\section{The time of transformation from the vegetative to the reproductive stages}

The histological examination of the shoot apex showed that the plants were still in their vegetative growth stage up to 56 days after germination. Through histological examination it was noted that the conversion from the vegetative into the reproductive stage started on the $60^{\text {th }}$ day after seed germination, when 1 out of 4 samples had the floral apex initiated. On the $65^{\text {th }}$ day after germination all plants had entered their reproductive stage (Table 1).

Table 1. The status of growth stage of glasshouse-grown $S$. formosa in relation to time after germination.

\begin{tabular}{ccc}
\hline \hline Plant age & \multicolumn{2}{c}{ Growth stage $(\%) *)$} \\
\cline { 2 - 3 } (after germination) & Vegetative & Reproductive \\
\hline 14-days & 100 & 0 \\
28-days & 100 & 0 \\
35-days & 100 & 0 \\
42-days & 100 & 0 \\
49-days & 100 & 0 \\
56-days & 100 & 25 \\
60-days & 75 & 75 \\
64-days & 25 & 100 \\
65-days & 0 & 100 \\
66-days & 0 & \\
\hline \hline
\end{tabular}

*) calculated from 4 plants for each treatment.

In addition to the histological examination, the number of nodes growing before the first flower was initiated was noted for 100 glasshouse-grown plants cultivated at the same time. The results presented in Table 2 show that the central stem grew more nodes before the initiation of the first flower, compared to the axillary branches.

Similarly, experiments conducted in growth chambers with three different photoperiods showed more nodes before the first flower initiation on the central stem than on the axillary branches (Table 3). No significant difference was found in the number of nodes, either on the central stem $(P=0.84)$ or axillary branches $(P=0.60)$, among the three photoperiod regimes tested. 
Table 2. Number of nodes before the first flower initiation on the central stem and axillary branches of glasshouse-grown S. formosa.

\begin{tabular}{lc}
\hline \hline Stems & Number of nodes*) \\
\hline Central stem & $9.95 \pm 0.19$ \\
Axillary branches & $7.87 \pm 0.13$ \\
\hline \hline
\end{tabular}

*) calculated from 100 plants.

Table 3. Number of nodes before the first flower initiation on the central stem and axillary branches of $S$. formosa grown under three different photoperiods.

\begin{tabular}{lccc}
\hline \multirow{2}{*}{ Stems } & \multicolumn{3}{c}{ Number of nodes according to photoperiod } \\
\cline { 2 - 4 } & 16 hours & 12 hours & 8 hours \\
\hline Central stem & $12.00 \pm 0.27$ & $12.18 \pm 0.20$ & $11.85 \pm 0.19$ \\
Axillary branches & $10.50 \pm 0.31$ & $10.65 \pm 0.24$ & $10.70 \pm 0.18$ \\
\hline \hline
\end{tabular}

*) calculated from 20 plants.

\section{Vegetative apex development}

The vegetative growth of $S$. formosa was slow at the beginning, particularly during the first 4 weeks after gemination. There was no sign of axillary bud formation during the first 2 weeks (Figure 1) but when the age of the plant reached 4 weeks after germination the initiation of axillary bud formation was clearly identified (Figure 2).

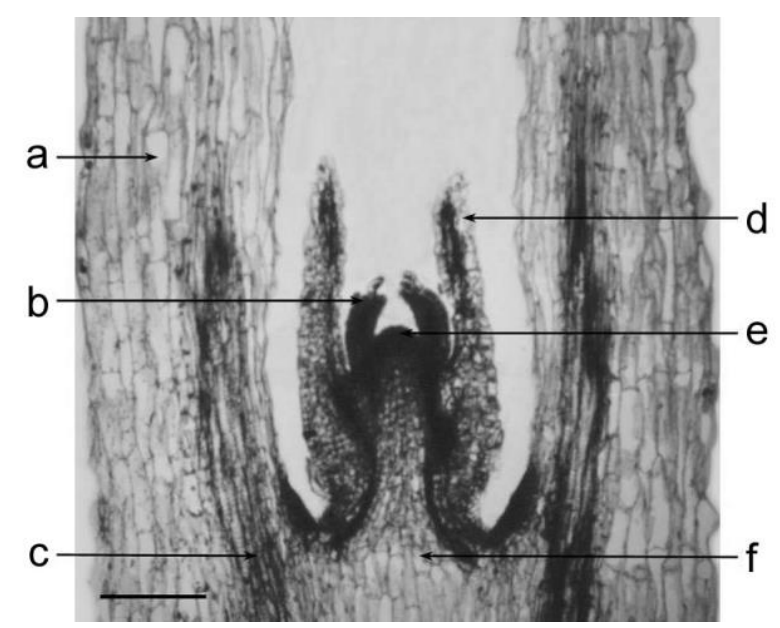

Figure 1. Longitudinal section of shoot apex of a 2-week old seedling of S. formosa (a, cotyledon; b, leaf primordium; c, procambium; d, first true leaf; e, apical meristem; $\mathrm{f}$, ground meristem). Bar $=100 \mu \mathrm{m}$. 


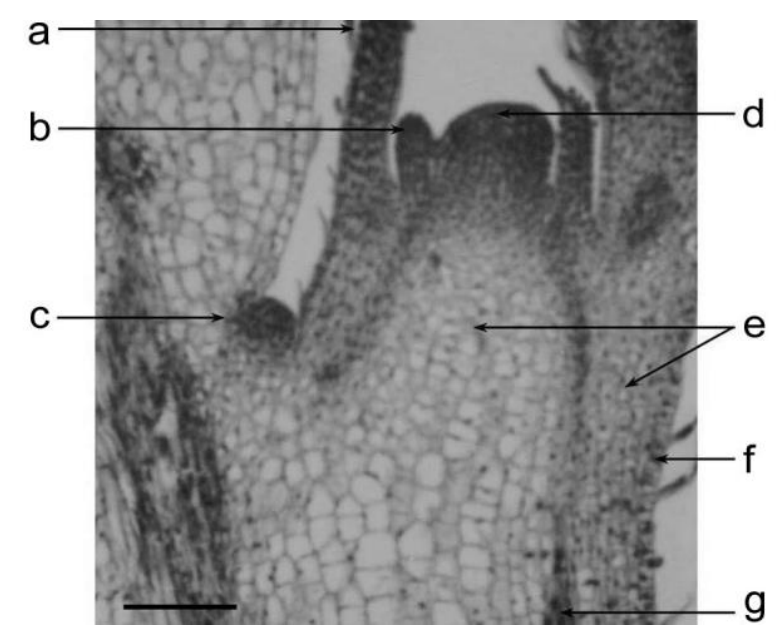

Figure 2. Longitudinal section of shoot apex of a 4-week old plant of $S$. formosa showing the apical meristem and primordia of leaves and axillary bud (a, young leaf; $b$, leaf primordium; c, axillary bud primordium; d, apical meristem; e, ground meristem; f, protoderm; g, procambium). Bar $=100 \mu \mathrm{m}$.

\section{Floral Apex Development}

Following the period of vegetative growth, plants entered the reproductive stage during which floral buds were initiated and developed in the leaf axils. This study showed that under the 12- to16-hour photoperiod the transformation from vegetative to floral apex in $S$. formosa started to occur from 60 days after germination (Table 1). Changes were clearly observed when the apical meristem entered the reproductive stage. It was found that the apical meristem grew upward and widened (Figure 3). The tunica and corpus organization was still identifiable in the floral meristem and the layer number in tunica and corpus was the same as in the vegetative stage. Following this, the floral buds developed in the leaf axil where axillary buds normally occurred, and the apical meristem continued to grow upward to form a thick apical dome so that new leaf and new floral primordia were developed (Figure 4).

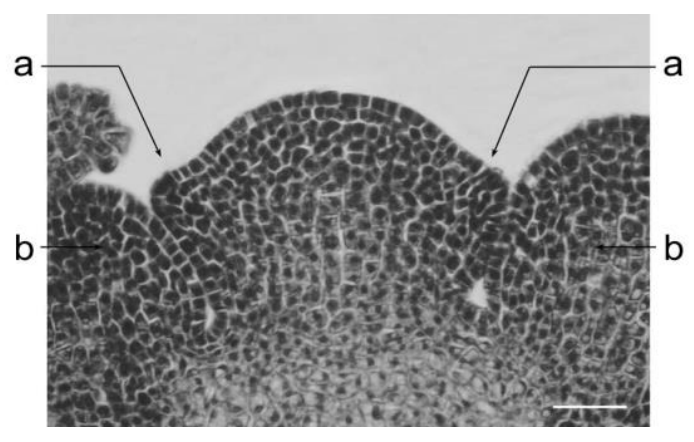

Figure 3. Longitudinal section of floral apex of $S$. formosa showing the widened apical meristem (a, leaf primordium; $b$, floral primordium). $B a r=25 \mu \mathrm{m}$. 


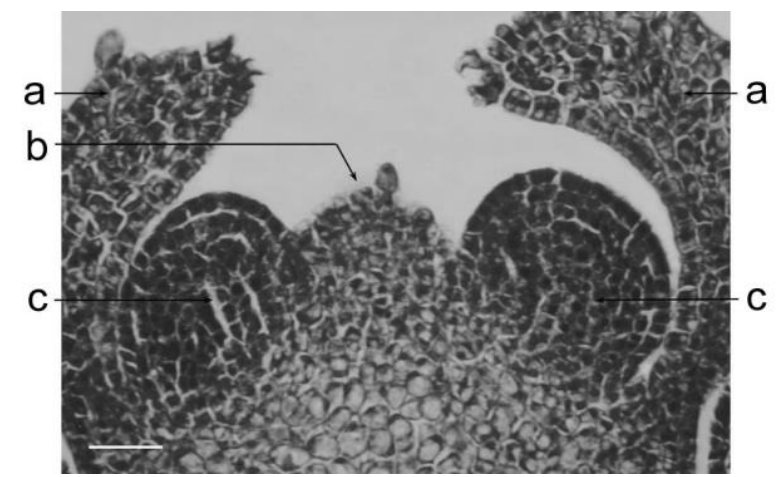

Figure 4. Longitudinal section of shoot apex of S. formosa showing two floral primordia and vegetative apical meristem that continues to grow ( $a$, leaf primordium; $b$, apical meristem; c, floral primordium). Bar $=25 \mu \mathrm{m}$.

Meanwhile, floral buds that arose from the leaf axils continued to grow into a shallow and comparatively broad expanse of meristematic tissue. The broad apex of the floral bud was occupied by a mantle of meristematic cells covering a vacuolated core of ground tissue no longer concerned with upward growth. The tunica and corpus organization was not identifiable in the floral meristem of S. formosa.

\section{DISCUSSION}

Based on its seasonal growth cycle, S. formosa is classified as an annual plant. This means that the entire cycle from seed to vegetative stage, from vegetative stage to flowering and from flowering to seed again occurs within a single growing season. A similar growth cycle is also found in other legumes such as Glycine max, Cicer arietinum and Phaseolus vulgaris, as well as in other plants such as Oryza sativa, Hordeum vulgare, Zea mays, Musa spp. and Helianthus annuus.

As with most plants, during its vegetative growth the shoot apex of $S$. formosa produced stems and leaves. A signal such as irradiance and $\mathrm{CO}_{2}$ concentrations triggered changes in the shoot apex metabolism resulting in the transformation from the vegetative into the floral apex and the plant entered the reproductive stage (Matsoukas et al., 2009). During this transformation, the floral buttress was initiated, this grew further into a floral bud, and finally into a flower cluster replacing the axillary bud at the leaf axil. Each flower cluster consisted of 5 to 7 flowers that were borne on a peduncle up to $15 \mathrm{~cm}$ long. 
Williams (1996) reported that S. formosa may start to flower within 70 to 84 days after germination and plants would flower all year round. Yusuf et al. (2002) gave a more precise figure on the relationship between photoperiod and first flower appearance on this plant. It was reported that plants grown under a longer photoperiod produced flowers faster than plants grown under a shorter photoperiod. Plants receiving a 16-hour photoperiod flowered within 61 days after germination. On the other hand, plants grown under 12- and 8-hour photoperiods, started to flower on the $66^{\text {th }}$ and $71^{\text {st }}$ day after germination, respectively. The observation of Yusuf et al. (2002), however, was based on visual examination of the floral buds. Histological investigations in this study supported their findings and suggested that the period between the $56^{\text {th }}$ and $60^{\text {th }}$ day after germination is critical for the conversion of vegetative growth to reproductive growth in S. formosa grown under a 12- to 16-hour photoperiod.

This study showed that although the time required for first flower initiation was influenced by photoperiod, the number of nodes among plants grown under the three different photoperiod regimes was not significantly different. Plants grown under the photoperiods of 16-, 12- and 8-hour per day using artificial light with an intensity of 150 to $1000 \mu \mathrm{mol} \mathrm{m} \mathrm{m}^{-1} \mathrm{~s}^{-1}$ produced more nodes, for both central stem and axillary branches, before the first flower initiation than plants grown in the glasshouse. The reason for this difference is due to the delay in the conversion from vegetative to reproductive growth occurring on plants grown in the growth chambers. The delay in growth could be attributed to the constant subtle vibration of the benches due to the air conditioning system in the growth chambers. This subtle vibration may induce stress on the plants (Andersen and Andersen, 2000) resulting in the increase in nodes before flowering. In addition, Taji et al. (1995) suggested that plants grown under stress conditions produced large amount of ethylene gas causing inhibition of plant growth and development. As a result, flowering was delayed and the plants developed more nodes before the first flower was initiated.

Although the difference in the number of nodes before the first flower, either on the central stem or axillary branches, on plants grown under the three photoperiod regimes was not significant, it was clear that more nodes were produced by the central stem. A similar pattern was also recorded on plants grown in the glasshouse. The reason for fewer nodes on the axillary branches than on the central stem is due to the sturdier growth of the central stem. The axillary branches of $S$. formosa grow as plagiotropic branches that have a poorer growth than the central stem (Sudhersan and AboEl-Nil, 2002). This could be due to the difference in hormonal balance, especially ethylene, in plagiotropic shoots. Blake et al. 8 
(1980) suggested that ethylene was involved in the plagiotropic growth of branches in Cupressus arizonica and could indicate changes in auxin or other compounds.

In addition to the critical period (between the $56^{\text {th }}$ and the $60^{\text {th }}$ day after germination) mentioned earlier, this study suggested that node 10 on the central stem and node 8 on the axillary branches are the critical nodes for the conversion from vegetative to reproductive growth in glasshouse-grown S. formosa. In addition, node 11 on the main stem and node 10 on the axillary branches are the critical nodes for the conversion from vegetative to reproductive growth on plants cultivated under growth chamber conditions.

\section{CONCLUSION}

Results from the histological study on the shoot apices of plants grown in the glasshouse under a 12- to16-hour photoperiod showed that the time between the $56^{\text {th }}$ and $60^{\text {th }}$ day after germination was the critical period for the conversion from vegetative to reproductive growth in this species. Therefore, it is suggested that any treatment to modify ploidy level in $S$. formosa should be given no later than 60 days after germination.

Another reliable indicator for the conversion from vegetative to reproductive growth in $S$. formosa has been the number of nodes produced before first flower initiation. The number of nodes growing before first flower initiation was not photoperiod-dependent. However, differences in the growth habit between the central stem and axillary branches resulted in more nodes being produced before first flower initiation on the central stem, compared to the axillary branches. The difference was also noted between plants grown under normal conditions (in the glasshouse) and under artificial conditions (in the growth chambers). Under normal conditions, 10 and 8 nodes were critical for the central stem and axillary branches, respectively for the initiation of the first flower. Meanwhile, under artificial conditions, the critical nodes were 11 and 10 for central stem and axillary branches, respectively. These critical nodes should be taken into account in the manipulation of ploidy levels in S. formosa. Antimitotic agents should be applied to the plants before they reach nodes $8-10$ depending on the conditions under which the plants are grown.

\section{REFERENCES}

Andersen, A. S. and L. Andersen. 2000. Growth regulation as a necessary prerequisite for introduction of new plants. Acta Hortic. 541: 183-188. 
Azhar, M. and I. Rusli. 2000. Optimising flow cytometric analysis for nuclear DNA in Musa spp. Tropical Plant Biology Research in Malaysia: Fruit and Vegetables 9: 345-349.

Blake, T. J., R. P. Harris and D. M. Reid. 1980. Ethylene, gibberellins, auxin and the apical control of branch angle in a conifer, Cupressus arizonica. Planta 148: 64-68.

Bruner, W. R. 1998. Tetraploid Passiflora incarnata. Passiflora (The Official Newsletter of Passiflora Society International) 8: 1-4.

Joshi, P. and R. C. Verma. 2004. High frequency production of colchicine induced autotetraploids in Faba bean (Vicia faba L.). Cytologia 69: 141-147.

Lucket, D. J. 1989. Colchicine mutagenesis is associated with substantial heritable variation in cotton. Euphytica 42: 177-182.

Matsoukas, I. G., B. Thomas, V. V. Ruiz, S. Jackson, A. Jackson and S. Adams. 2009. Juvenile phase change: Towards a physiological and genetic understanding, 196-197, Society for Experimental Biology Annual Main Meeting, $28^{\text {th }}$ June $-1^{\text {st }}$ July 2009 , Glasgow, UK.

McCuistion, F. and T. C. Wehner. 2002. Seedless watermelon breeding. Department of Horticultural Science NC State University, Raleigh.

Prakash, N. 2000. Methods in Plant Microtechnique. University of New England, Armidale, Australia.

Sudhersan, C. and M. AboEl-Nil. 2002. Somatic embryogenesis on Sturt's desert pea (Swainsona formosa). Sci. Corr. 83: 1074-1076.

Taji, A. M., W. A. Dodd and R. R. Williams. 1995. Plant Tissue Culture Practice. University of New England, Armidale.

Takamura, T. and I. Miyajima. 1996. Colchicine induced tetraploids in yellow-flowered cyclamens and their characteristics. Sci. Hortic. 65: 305-312.

Tulay, E. and M. Unal. 2010. Production of colchicine induced tetraploids in Vicia villosa Roth. Caryologia 63: 292-303.

Williams, R. R. 1996. Swainsona formosa, (Clianthus, Sturt's desert pea), family Fabaceae (Leguminosae). In K. A. Johnson and M. Burchett [eds.], Native Australian Plants: Horticulture and Uses. University of New South Wales Press, Sidney, Australia.

Yusuf, R., A. Taji and R. Jessop. 2002. The effect of temperature and photoperiod on flowering of Sturt's Desert Pea (Swainsona formosa), an Australian native legume. In A. Taji and R. Williams [eds.], The Importance of Plant Tissue Culture and Biotechnology in Plant Sciences, 369-375. University of New England, Armidale, New South Wales.

Zulkarnain. 2004. The production of tetraploid Swainsona formosa by colchicine mutagenesis. Zuriat 15: 60-64. 